\title{
CULTURAL - RELIGIOUS TOURISM IN DOBROGEA, ROMANIA - SPECIFIC AND TENDENCIES
}

DOI: https://doi.org/10.18509/GBP210335d

UDC: 338.48-6:7/8(498)

338.48-6:2(498)

\author{
Alina Viorica Dumitrascu ${ }^{1}$ \\ Camelia Teodorescu ${ }^{2}$ \\ Bogdan Petre ${ }^{1}$ \\ Cristian Cazacu ${ }^{1}$ \\ Andrei Ducman ${ }^{2}$ \\ ${ }^{1}$ University of Bucharest, Faculty of Geography, "Simion Mehedinti” Doctoral School, \\ Bucharest, Romania \\ ${ }^{2}$ University of Bucharest, Faculty of Geography, Department of Human and Economic \\ Geography; Bucharest, Romania CAIMT (Research Center for Integrated Analysis and \\ Territorial Management), University of Bucharest, Romania
}

\begin{abstract}
The monuments of religious culture spreading within the areal between the Danube River and the Black Sea, that means within the historical province of Dobrogea, represent a great attraction for all those who are interested in getting closer to the first Christians on the territory of Romania. Our study is based upon the analysis of the important historical monuments that exist in this province, on the behavior of the tourists visiting them, as well as on the attitude of the residents in the sense of sustaining the development of the religious tourism. On the methodological perspective, there are followed many aspects, as there is made the empirical analysis of the questionnaires applied to the residents and tourists as well. The results highlight differentiated attraction of the tourists towards the monuments that preserve the traces of the first Christian martyrs, of the religious monuments bearing outstanding spiritual value as compared to the ones destined to religious service only. Their old age and spirituality contribute to the amplification of the pilgrimage phenomenon and to the increase of the numbers of touristic visits, especially for the tourist coming for the first time in those places. The role of the residents should get bigger and bigger in maintaining this phenomenon, which is a thing which people are less conscious about. Therefore, the tourism- purposed infrastructure does not have the same upheaving evolution. The two elements, the religious attraction relying in the number of tourists who visit the religious monuments of Dobrogea, on the first hand, and the accommodation structures, the public food service providers, as well as the number of employees functioning in the tourism sector of the referred province, on the other hand, they both present different evolution trends.
\end{abstract}

Keywords: religious monuments, tourism, Christian martyrs, Dobrogea, religion

\section{INTRODUCTION}

The cultural patrimony represents a possible touristic resource. Cultural tourism is that form of tourism which emphasizes the cultural resources in a certain geographical area from a touristic viewpoint [19], [7], [5], [8], [7]. The valorization of touristic monuments will always represent one of the greatest attractions. Monuments keep the memory of their 
creators alive. A variety of comparisons are drawn between the religious, cultural, historical and geographical diversity [2], [6], [9], [12].

The attraction towards cultural tourism is becoming more and more obvious, especially when it comes to discovering the cultural values from a certain geographical area such as Dobrogea, where certain events, marked today through of religious monuments, took place. [1], [3], [10], [4]. All these material prints are attractive today for the tourists interested not only in religious monuments but also in cultural values [13], [16, [18]. Educational or school tourism represents another form of tourism which can offer the necessary information in order to create a complete image of a geographical area, such as Dobrogea in Romania, where, by means of game playing, this past can become known and understood. The whole image can be obtained through detailed research carried on specific historical monuments [18], [20]. From this point of view, religious monuments emphasize the presence of personalities from early Christian times. Religious monuments complete the entire cultural aspect of a given space [14], [17]. The life of a community is hard to imagine without a religious life [11]. The materialization of beliefs is reflected in this study by means of these monuments (Figure 1).

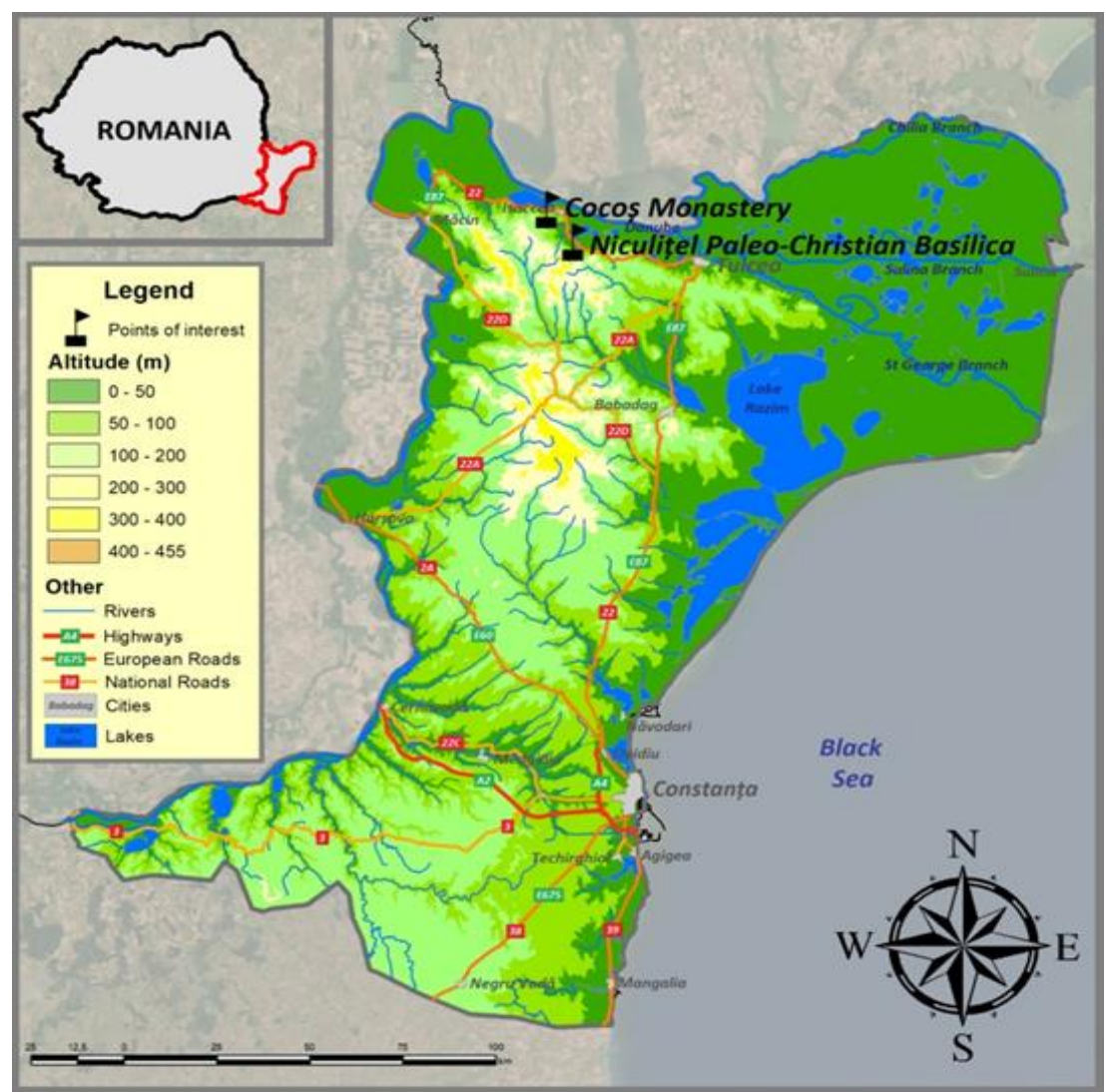

Figure 1. Map showing the location of the Paleochristian monument from Niculitel and of the Cocos Monastery in Dobrogea, Romania

\section{METHODOLOGY}

The methodology followed a series of steps. First of all, there was an analysis of the cultural-historical monuments included in the list of patrimony monuments, published in 2016 by The Ministry of Culture and the National Patrimony of Romania. Out of these monuments, the Paleochristian Monument from Niculitel was selected as it is considered to be of major importance following the discovery of the crypt in which the material traces 
of the four martyrs were discovered, that is, the relics of those who contributed to spreading Christianity in Romania, in its early stages. Another step was a chronological presentation of the discovery of the bones of the first Christian martyrs in Dobrogea, Romania as well as the fact that they were moved to the nearby Cocos Monastery. The last step encompasses some of the answers provided by the visitors and the tourists who reached the two important monuments. After the empirical analysis of the interviews and discussions carried with those who have visited the two monuments, we could notice an understanding on their part of the role played by these Christian martyrs, as well as the amenities to the Niculitel monument.

\section{RESULTS AND DISCUSSIONS}

An analysis of the first Dobrudjan historical monuments implies the existence of the first Christian martyrs and the presence of religious buildings which have a special architecture. Romanians emerged in history as a Christian people. An old tradition, still circulating today, tells that Saint Andrew, the Apostle, proclaimed the word of the Gospel in the South-Eastern parts of Romania, especially in the area near the Black Sea where the first local church and the first Episcopalian centre were built in the 4th century AD, located in Tomis (today's Constanta). The archaeological research which has taken place in Dobrogea up to now, has brought to light 36 Paleochristian edifices dating from centuries IV - VII AD. Twelve of these were built in the 4th century AD [11]. Culturalreligious tourism could represent an attractive form of tourism in Dobrogea. Here was the first Christians recorded, here they suffered the repercussions for supporting Christianity. Historical religious monuments are well-used. The material traces which can be valorized as touristic attraction nowadays can also be included in a touristic circuit whose identification and promotion elements could be ,the first Christian martyrs"[15], [16]. The Paleochristian basilica with crypt from Niculitel is a historic monument located in the North-Eastern part of the village of Niculitel, at the bottom of Piatra Rosie Hill, no 1, Museum Street. It can be found at about $10 \mathrm{~km}$ from the Noviodunum Roman Camp and 29 km from Tulcea (Fig. 2 and Fig. 3).

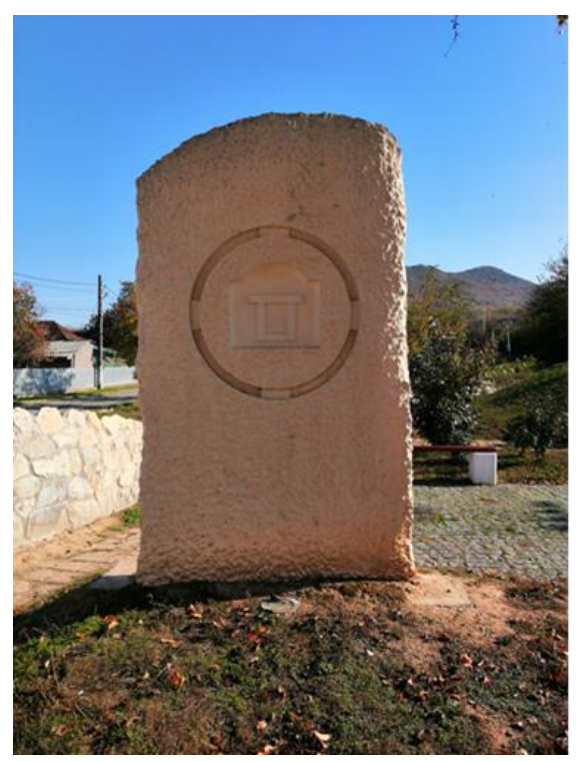

Figure. 2. The Paleochristian Basilica patrimonial symbol

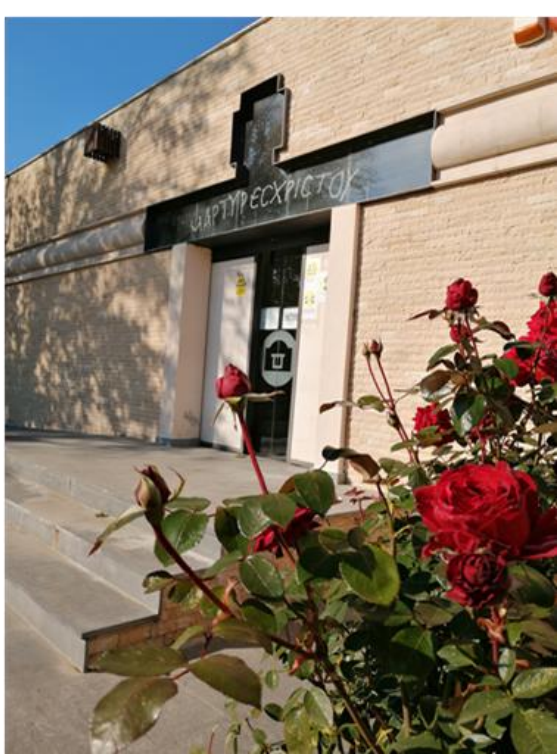

Figure.3.The façade and the entrance to the Paleochristian Basilica from Niculitel 
The rich archaeological patrimony that the village of Niculitel displays, was enriched in 1971 by the discovery of the martyr basilica built on top of a crypt where there were the relics of fours saints Zotikos, Attalos, Kamasis și Filippos (throughout time, the names of these saints have become Romanized - Zotic, Atal, Camasie și Filip, but the inhabitants of Niculitel use their Greek names), protected by a wooden funeral scraper. This unique and extraordinary artefact, less known to the general public, represents the oldest Christian scrape preserved and known to the world so far. It is exhibited in the History and Archaeology Museum from the „Gavrilă Simion” Institute of Eco-Museum Research from Tulcea. In September 1971 a highly-important discovery was made, which further emphasizes the seniority and force of the Dacian-Roman Christianity. This is a Paleochristian Basilica, which has three vessels and a semi-circular apse (altar), discovered in Niculițel, Tulcea county (fig. 4 and fig. 5). The villagers smashed the truncated spur on top of the dome and small portions from its brickwork, deteriorated part of the inner tomb because of the sliding of sawdust. Archaeological excavations took place in an inhabited area, at the intersection of two pedestrian walkways. The value of this basilica lies in its crypt with martyr relics (martyrdom), which has a square shape $(3,70 \times 3,40)$ and is made from brick and sawdust - placed under the altar; inside the crypt a wooden scrape was found in which there were the relics of four martyrs; inside, on the left-side wall, a Greek inscription was scratched on the wet sawdust: „Christ's Martyrs”; and on the right-side wall there is once again the word ,martyrs” as well as their names: Zotikos, Attalos, Kamasis and Filippos [11].

Over the next years, as archaeological research continued, remains from the bodies of other martyrs, whose names are unknown, were discovered under this crypt. On a limestone slab there is an inscription, with the following lines: „Here and there (there is) the blood of the martyrs". For the first time, in the Paleochristian vocabulary martyrs are considered saints at Niculitel. Archaeologists and theologians who dealt with these discoveries from Niculitel could not set the date and time when these six martyrs suffered. Most of them consider that they were martyred in the nearby village of Noviodunum (today, the town of Isaccea), either during the persecution of Diocletian, around 303-304 A.D., or during the time of emperor Liciniu who took several measures against Christians, between 319-324 A.D. [11].

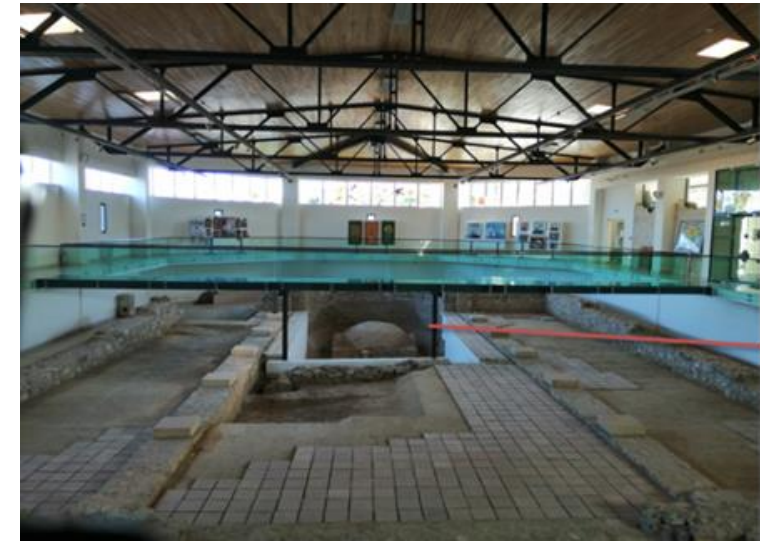

Figure. 4. The inside of the Niculitel Museum and the crypt where the relics of the first Christin martyrs were discovered.

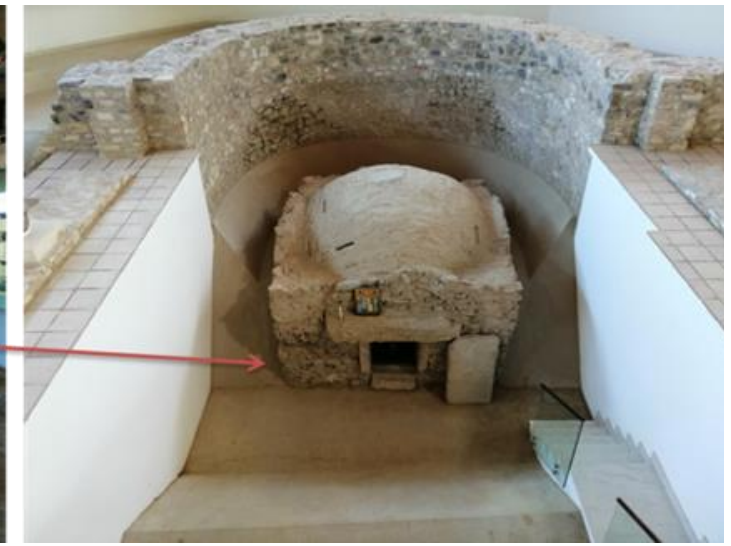

Figure. 5. Detail- the crypt where the relics of the four Christin martyrs were discovered 
In the second half of the 4th century A.D., a basilica was built on top of the place where they had been buried, so as to honour them every year. It may be either this Paleochristian religious place - or a monastery that might have been built later - which gave the village the name Mănăstiriște, encountered in a few medieval sources. In time, a lot of difficult occurrences came over the place, such as wars, enslavement, and desolation brought about by many invading peoples, which also led, among others, to a decay of the Noviodunum citadel, as well as of many other wealthy settlements and churches in Dobrogea.

At the same time with the amenities brought to the Paleochristian monument from Niculitel, the relics of the four Christian martyrs were moved to the Cocos Monastery (fig. 6 and fig. 7). The number of people visiting these two monuments is growing with every year that goes by. As a result of the discussions with the people who visit these places, most of them express their satisfaction regarding the degree of embellishment and restoration of the Niculitel Monument, considering it ,the most successful restoration of a Dobrudjan monument". The efforts made to preserve it are equally appreciated and so is giving the possibility to make these important monuments of Christianity in Romania known to those who succeed in visiting them, as they are inter-connected: one in which the relics of the four Christian martyrs were discovered and the second one in which they are preserved. Each of these two monuments represents a real source of information when it comes to knowing the history of Dobrogea, that anyone might be interested in.

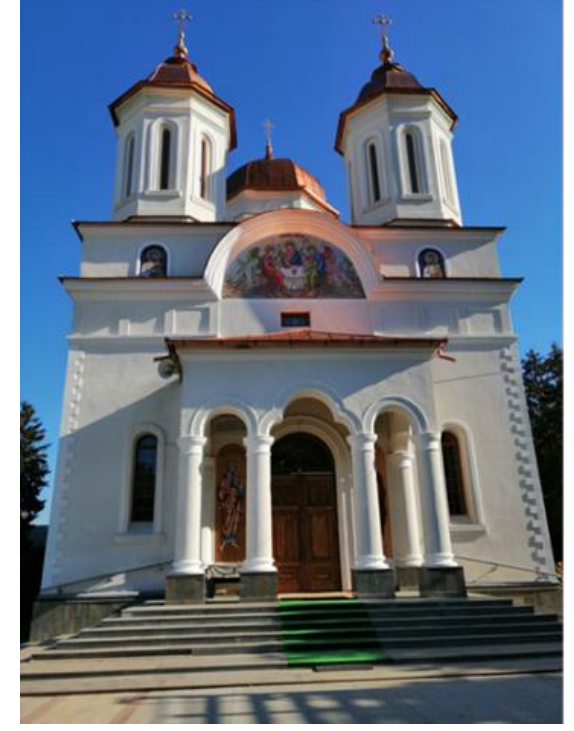

Figure 6. Cocos Monastery, the Western façade, the entrance

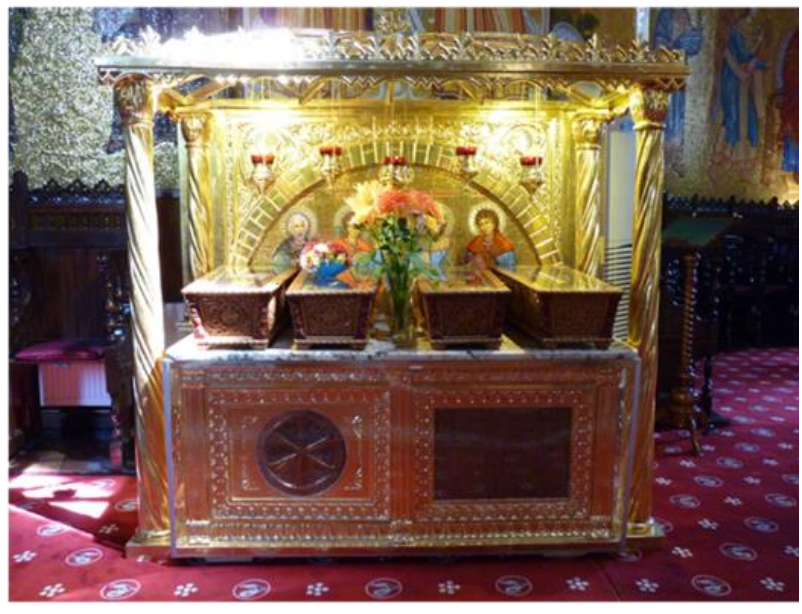

Figure 7. The relics of the four Christian martyrs - the inside of the Monastery

The museum creates an elegant, aerated and pleasant inner space. The perimeter gallery destined to the flow of visitors, maintains a permanent visual contact with the monument, and the permanent display of Paleochristian objects, coloured photographs and slides complete the visit of the entire Paleochristian ensemble. Such monuments support the idea of getting to know history, culture in general and religious culture in particular. Dobrogea is a historical Romanian province with a rich cultural patrimony offered by the multitude of ethnic groups living here, whose specific monuments might contribute to the development of local cultural tourism [19], [15]. 


\section{CONCLUSIONS}

The existence of historical and cultural monuments can have a beneficial effect on those who visit these places and on the lives of the inhabitants. A sustainable economic activity must start from the premise that it brings additional quality to their lives. In this case, in the entire Dobrogea, the region between the Danube and the Sea, the cultural patrimony and the religious monuments especially might represent a real source of attraction. Cultural tourism represents one of the real forms of tourism which might come across as one of the economic alternatives in Dobrogea.

The Niculitel basilica brings originality, uniqueness and specificity to the national and universal culture. At a national level, this monument is very important in our history, because it is here where the first relics of martyrs from the Paleochristian era, discovered on the territory of Romania, were kept. Today, their relics are placed to be honoured in the church belonging to the nearby Cocos Monastery.

The martyrs' crypt is very well-preserved which allows for tourism to take place, being accessible to those interested in visiting it.

\section{REFERENCES}

[1]Alvarez J.J., To exist with and for the people: Philosophico-Religious roots and the need of a moral common faith, Politics and Religion Journal, vol.13, issue 1, pp.97-112, 2019

[2] Barrera-Fernandez D. \& Hernandez-Escampa M., The impact of urban policy in the management of the tourist-historic city: a comparative study, Pasos-Revista de Turismo y Patrimonio Cultural, vol. 14, Issue 3, pp. 705-724, 2016

[3] Besschetnova Elena, The idee of Christian Unity at the End of the Nineteenth Century, Church History and Religious Culture, vol. 99, Issue 1, pp. 46-63, 2019

[4] Costa Hilário, Ana Catarina \& Marreiro das Chagas, Márcio, Influencia del escultismo en la formación personal y social de los scouts por medio de la práctica del turismo ecológico y pedagógico, Estudios y Perspectivas en Turismo, vol. 23, Issue 3, pp. 484-50, 2014

[5] Dincă Iulian \& Camelia Teodorescu, The Romanian rural space and its landscapes: attraction and motivation for relocating townspeople, Geographia Napocensis, vol. 1, pp 21-36, 2015

[6] Grecu Alexandra, Andreea Karina Gruia, Marian Marin, Mariana Bănuță, Cosmin Olteanu, Ionuț Constantin, Mihaela Gadoiu, Camelia Teodorescu, Răzvan Cătălin Dobrea \& Cristian Constantin Drăghici, Specificity of Sustainable Structural Dynamics of Local Economy in Romanian Tourist Resorts, Sustainability, Vol. 11, issue 24, pp. 7155-7167, 2019

[7] Herman G.V., Varnav R., Design elements for promoting attraction case study: Tara Oasului museum (Satu Mare County), Geojournal of tourism and geosites, vol. 14 / issue 2, Oradea, Romania, pp. 168-177, 2014

[8] Kopiec Piotr, The idea of the Biblical economics: Utopia or chance in the of the contemporary transformation of the sphere of work, HTS Teologiese Studies-Theological Studies, vol. 75, Issue 4, 2019

[9] Muresan, I.C., Oroian, C.E., Harun, R., Arion, F., Porutiu, A., Chiciudean, G., Todea, A. \& Lile, R., Local Residents' Attitude Toward Sustain $\neg$ able Rural Tourism development, Sustainability, Vol. 8, pp 2-14, 2016

[10] Oliver Willem H., Erna, God as One, HTS Teologiese Studies-Theological Studies, vol. 75, Issue 1, 2019

[11] Păcurariu, M., Istoria Bisericii Ortodoxe Române, vol. I, Ed. a II-a, București, 1992.

[12] Pintilii Radu-Daniel, Daniel Peptenatu, Ana-Maria Ciobotaru, Sorin George Toma, Ana Maria Grigore, Cristian-Constantin Drăghici, Răzvan-Cătălin Dobrea, Adrian Gabriel Simion, 
Ion Andronache, Camelia Teodorescu \& Daniel Constantin Diaconu, Creative economies in Romania-spatial projections and trends, Bulletin of Geography. Socio-economic Series, Poland, vol. 37, pp 95-108, 2017

[13] Rădoi Irina-Valentina, Andrei Ducman, Camelia Teodorescu, Marian Marin \& Alexandru Gogioiu, The impact of the development of the local economy on the natural environment of the Danube Delta, Romania, Proceedings, Public recreation and landscape protection, Krtiny, Czech Republic 2020, pp. 489

[14] Szemkovics Laurentiu Stefan, Camelia, Teodorescu, Alexandra Grecu, Karina Gruia, Alina Mareci \& Nicoleta, Bira, The relevance of the historical monuments in the development of the cultural tourism in the main cities of the Region of Oltenia, Romania, Quaestus Journal, Timisoara, Romania, vol. 12, Issue 2, pp. 42-54, 2018

[15] Teodorescu Camelia \& Laurentiu Stefan Szemkovics, The ethno-creativity in the pilot centers in Romania and their role in the development of cultural tourism and the educational process, Forum geografic Geographical studies and environment protection research, Craiova, Romania, vol. 16, nr. 1, pp. 88-97, 2017

[16] Teodorescu Camelia, Daniel Diaconu \& Roxana Radu, Disfunctionalities in the Organization and Development of SPA Tourism Developed on Salt Resources in Maramures, Romania, Public recreation and landscape protection, Krtiny, Czech Republic, pp. 101-105, 2019

[17] Teodorescu Camelia, Octavian Teodorescu, Nicoleta Bira, Badea Alin \& Badea Livia Florina, Religious and cultural tourism and the socio-economic and educational implications, Quaestus Multidisciplinary Research Journal, vol. 8, pp. 227-285, 2016

[18] Teodorescu Camelia, Radu-Daniel Pintilii, Peptenatu Daniel, Teodorescu Octavian \& Toma Sorin George, Popularizing Cultural Identity Through Religious Tourism-Socio-Economic and Educational Implications, International Multidisciplinary Scientific GeoConference: SGEM: Surveying Geology \& mining Ecology Management, vol.3, pp. 947-954, 2016

[19] Teodorescu Camelia, Turism cultural, Editura Transversal, Targoviste, 2009

[20] Vester Pieter, Challenges of the diversity of languages in churches: The unity of the church and language, Tydskrif Vir Geesteswetenskappe, vol. 59, Issue 2, pp. 192-202, 2019 